\title{
A unique protein profile of peripheral neutrophils from COPD patients does not reflect cytokine- induced protein profiles of neutrophils in vitro
}

Jeroen D Langereis, René C Schweizer, Jan-Willem J Lammers, Leo Koenderman ${ }^{*}$ and Laurien H Ulfman

\begin{abstract}
Background: Inflammation, both local and systemic, is a hallmark of chronic obstructive pulmonary disease (COPD). Inflammatory mediators such as TNF $\alpha$ and GM-CSF are secreted by lung epithelium, alveolar macrophages and other inflammatory cells and are thought to be important contributors in the pathogenesis of COPD. Indeed, neutrophils are activated by these cytokines and these cells are one of the major inflammatory cell types recruited to the pulmonary compartment of COPD patients. Furthermore, these inflammatory mediators are found in the peripheral blood of COPD patients and, therefore, we hypothesized that TNF $\alpha / G M-C S F-i n d u c e d$ protein profiles can be found in peripheral neutrophils of COPD patients.

Methods: Using fluorescence 2-dimensional difference gel electrophoresis we investigated differentially regulated proteins in peripheral neutrophils from COPD patients and healthy age-matched control subjects. Furthermore, protein profiles from COPD patients were compared with those of neutrophils of healthy age-matched controls that were stimulated with TNF $\alpha$ and/or GM-CSF in vitro. Protein gels were compared using DeCyder 7.0 software.

Results: We identified 7 significantly regulated protein spots between peripheral neutrophils from COPD patients and age-matched healthy control subjects. Stimulation of peripheral neutrophils with TNF $\alpha$, GM-CSF or TNF $\alpha+$ GM-CSF in vitro resulted in 13, 20 and 22 regulated protein spots, respectively. However, these cytokine-induced protein differences did not correspond with the protein differences found in neutrophils from COPD patients.

Conclusion: These results show that neutrophils from COPD patients have a unique protein profile compared to neutrophils from healthy age-matched controls. Furthermore, the neutrophil profiles of COPD patients do not reflect putative dominant signals induced by TNF $\alpha, G M-C S F$ or their combination. Our results indicate that systemic neutrophil responses in COPD patients are caused by a unique but subtle interplay between multiple inflammatory signals.
\end{abstract}

\section{Background}

COPD is classified by the guidelines of the Global Initiative for Chronic Obstructive Lung Disease, which is based on lung function parameters: forced expiratory volume in 1 second $\left(\mathrm{FEV}_{1}\right)$ and forced vital capacity (FVC) [1]. However, it has become increasingly clear that the GOLD classification does not represent the complex local and systemic inflammation in COPD [2-4]. Part of this inflammatory process is the secretion of inflammatory mediators by lung epithelium, alveolar macrophages and other inflammatory cells [5]. These inflammatory

\footnotetext{
* Correspondence: L.Koenderman@umcutrecht.nl

Department of Respiratory Medicine, University Medical Center, Heidelberglaan 100, 3584 CX Utrecht, the Netherlands
}

mediators affect the local tissue and attract inflammatory cells to the site of inflammation. For instance, alveolar macrophages secrete tumor necrosis factor- $\alpha$ (TNF $\alpha)$ [6] and granulocyte macrophage-colony stimulating factor (GM-CSF) [7] upon stimulation with cigarette smoke and increased levels of these cytokines are measured in the bronchiolar alveolar lavage (BAL) fluid, sputum or peripheral blood of COPD patients [8-12]. A central role for GM-CSF in smoke-induced inflammation was shown by intranasal administration of anti-GM-CSF antibodies to mice exposed to cigarette smoke, which reduced BAL fluid macrophages, neutrophils and TNF $\alpha$ synthesis [13]. Increased levels of TNF $\alpha$ were found in exhaled breath condensates [14], sputum [15] and serum of COPD patients [16-18]. 
Elevated cytokine levels in serum are frequently found in COPD patients $[11,16-20]$. However, these differences are often small compared to healthy controls, and the biological activity of these cytokines is dependent on the ratio with their naturally occurring inhibitors and other cytokines. Therefore, the use of peripheral neutrophils that have integrated all pro- and anti-inflammatory signals in vivo might be a more biologically relevant read-out to measure the systemic inflammatory status of a COPD patient. Previous studies in our laboratory showed that stimulation of neutrophils with either TNF $\alpha$ or GM-CSF in vitro resulted in differential expression of genes encoding chemokines and cytokines [21]. Various genes were similarly induced upon stimulation with TNF $\alpha$ or GMCSF. More interestingly, the combination of these cytokines induced a unique mRNA pattern, which was distinct from the profiles induced by either cytokine alone. For instance, GM-CSF did not affect the expression of CD83 mRNA in control cells, but inhibited its expression induced by TNF $\alpha$. This GM-CSF-induced inhibition was dose-dependent and was confirmed at the protein level by Western blot analysis [22]. These results show that integration of multiple cytokine signals can result in a distinct phenotype of the neutrophils.

Our study was designed to define the protein profiles of neutrophils found in COPD patients and to compare these with protein profiles found after in vitro stimulation. We performed fluorescence 2-dimensional (2D) difference gel electrophoresis (DIGE) on peripheral neutrophils from COPD patients and age-matched healthy controls and compared the differentially regulated proteins with differentially regulated proteins induced by TNF $\alpha$ and/or GMCSF in vitro. We report 7 protein differences in neutrophils from COPD patients compared to neutrophils from healthy age-matched control subjects. TNF $\alpha$, GM-CSF or TNF $\alpha+$ GM-CSF stimulation in vitro resulted in 13, 20 and 22 protein differences, respectively. Although cytokine stimulation of peripheral neutrophils in vitro showed differential protein expression, this did not correspond to differential protein expression found in neutrophils from COPD patients. Therefore, the peripheral neutrophil proteins regulated in COPD patients did not resemble TNF $\alpha$ or GM-CSF-induced protein profiles. However, differential protein expression in neutrophils from COPD patients compared to age-matched healthy controls shows that using this technique a disease related neutrophil profile could be found.

\section{Methods}

\section{Reagents}

Ficoll-Paque was obtained from GE Healthcare (Uppsala, Sweden). Human serum albumin (HSA) was from Sanquin (Amsterdam, the Netherlands). Recombinant human TNF $\alpha$ was purchased from Roche (Indianapolis, IN).
Recombinant human GM-CSF was a gift from Prof. A. Lopez (Institute of Medical and Veterinary Sciences, Adelaide, Australia). All other materials were reagent grade.

\section{Patients and healthy control subjects}

We included 13 patients with a diagnosis of COPD according to the Global Initiative for Chronic Obstructive Lung Disease (GOLD) [1] and 6 healthy age-matched control subjects (see for demographics table 1). All patients had stable COPD without an exacerbation in the last four weeks before entering the study. Patients with other inflammatory conditions, heart failure and treatment with oral glucocorticosteroids were excluded. Dyspnea was rated with the Medical Research Council (MRC) scores [23]. The medical ethics committee of the University Medical Center Utrecht (Utrecht, The Netherlands) approved the study, and all subjects provided written informed consent.

\section{Granulocyte isolation}

Granulocytes were isolated from whole blood anticoagulated with sodium-heparin from COPD patients or

Table 1 Characteristics of study subjects

\begin{tabular}{|c|c|c|c|}
\hline Characteristics & $\begin{array}{l}\text { Control } \\
(n=6)\end{array}$ & $\begin{array}{l}\text { COPD } \\
(n=13)\end{array}$ & Statistics \\
\hline Age. $Y r$ & $60.3(3.5)$ & $65.5(2.5)$ & n.s. \\
\hline \multicolumn{4}{|l|}{ Gender } \\
\hline Male & 5 & 11 & \\
\hline Female & 1 & 2 & \\
\hline \multicolumn{4}{|l|}{$\mathrm{FEV}_{1}$} \\
\hline L & $3.33(0.44)$ & $1.40(0.16)$ & 0,006 \\
\hline$\%$ predicted & $104.5(8.4)$ & $46.8(4.9)$ & $<0.001$ \\
\hline $\mathrm{FEV}_{1} / \mathrm{FVC}$ ratio & $78.0(2.0)$ & $45.4(4.4)$ & $<0.001$ \\
\hline \multicolumn{4}{|l|}{ GOLD } \\
\hline$\|$ & & 5 & \\
\hline III & & 6 & \\
\hline IV & & 2 & \\
\hline \multicolumn{4}{|l|}{ MRC score } \\
\hline 0 & 6 & & \\
\hline 1 & & 4 & \\
\hline 2 & & 4 & \\
\hline 3 & & 5 & \\
\hline \multicolumn{4}{|l|}{ Smoking status } \\
\hline Current smokers & & 2 & \\
\hline Ex-smokers & 3 & 11 & \\
\hline Never smokers & 3 & & \\
\hline Weight. kg & $74.7(3.6)$ & $81.7(3.8)$ & n.s. \\
\hline Height. cm & $175(4)$ & $178(3)$ & n.s. \\
\hline BMI. kg/m² & $24.4(0.8)$ & $25.8(0.9)$ & n.s. \\
\hline hsCRP, mg/L & $3.8(2.4)$ & $4.6(1.8)$ & n.s. \\
\hline Leukocyte cell count. $\times 10^{6}$ cells $/ \mathrm{mL}$ & $6.7(0.8)$ & $8.1(0.5)$ & n.s. \\
\hline \multicolumn{4}{|c|}{ Data is represented as mean \pm standard error of the mean } \\
\hline
\end{tabular}


age-matched healthy control subjects. Blood was diluted 2.5:1 with PBS containing trisodium citrate $(0.4 \% \mathrm{w} / \mathrm{v}, \mathrm{pH} 7.4)$ and human pasteurized plasmaprotein solution $(4 \mathrm{~g} / \mathrm{L})$. Mononuclear cells and granulocytes were separated by centrifugation using Ficoll-Paque. Erythrocytes were lysed in isotonic ice-cold $\mathrm{NH}_{4} \mathrm{Cl}$ solution $\left(8.3 \mathrm{~g} / \mathrm{L} \mathrm{NH}_{4} \mathrm{Cl}, 1 \mathrm{~g} / \mathrm{L} \mathrm{KHCO}_{3}\right.$ and $37 \mathrm{mg} / \mathrm{L}$ EDTA) followed by centrifugation at $4{ }^{\circ} \mathrm{C}$. After isolation, granulocytes were washed in PBS containing trisodium citrate $(0.4 \% \mathrm{w} / \mathrm{v}, \mathrm{pH} 7.4)$ and human pasteurized plasma-protein solution $(4 \mathrm{~g} / \mathrm{L})$ and resuspended in HEPES buffered RPMI 1640 supplemented with $0.5 \%$ (w/v) HSA. Purity of neutrophils was $>95 \%$ with eosinophils as major contaminant.

\section{Neutrophil stimulation and protein extracts preparation}

Neutrophils $\left(5 \times 10^{6} / \mathrm{mL}\right)$ in HEPES buffered RPMI 1640 supplemented with $0.5 \%(\mathrm{w} / \mathrm{v}) \mathrm{HSA}$ were incubated for $30 \mathrm{~min}$ at $37^{\circ} \mathrm{C}$. Subsequently, neutrophils of COPD patients and healthy age-matched controls were immediately prepared for protein extracts (see below). Furthermore, neutrophils of healthy age-matched controls were incubated without cytokines or stimulated with TNFa $(100 \mathrm{U} / \mathrm{mL})$, GM-CSF $(100 \mathrm{pM})$ or both for 4 hours at $37^{\circ} \mathrm{C}$. All neutrophil samples $\left(1.10^{7} /\right.$ sample) were washed twice (0.34 $\mathrm{M}$ sucrose, $1 \mathrm{mM}$ EDTA, $10 \mathrm{mM}$ Tris) and lysed in lysis buffer (10 mM Tris pH 7.4, 10\% glycerol, 1\% NP40, $50 \mathrm{mM} \mathrm{NaF}, 20 \mathrm{mM}$ tetra-Na pyrophosphate, $1 \mathrm{mM}$ DTT, $2 \mathrm{mM}$ vanadate, $1 \mathrm{mM}$ PMSF, $2 \mathrm{mM}$ DFP and $1 \times$ Complete EDTA-free protease inhibitor cocktail tablet (Roche)). Proteins were precipitated with $80 \%$ acetone and dissolved in labeling buffer ( 8 M Urea, $2 \mathrm{M}$ Thiourea, 4\% CHAPS, $10 \mathrm{mM}$ Tris $\mathrm{pH}$ 8.5).

\section{CyDye labeling}

The DIGE technology is based on differential protein labeling with different fluorescent CyDyes, which allows sample multiplexing. This method is an unbiased approach to identify differences in protein expression and the use of an internal standard enables identification of protein differences as small as 10\% [24]. Protein extracts were labeled using the fluorescent cyanine dyes developed for 2D-DIGE technology (GE Healthcare) following manufacturer's protocol with some minor modifications. Protein extracts $(30 \mu \mathrm{g})$ were labeled with $300 \mathrm{pmol}$ of fluorescent dye $(\mathrm{Cy} 2, \mathrm{Cy} 3$, or $\mathrm{Cy} 5)$. Protein samples from $\mathrm{COPD}$ patients, healthy control or in-vitro stimulated neutrophils were randomly labeled with $\mathrm{Cy} 3$ or $\mathrm{Cy} 5$. And each dye was used a similar number of times in each group to exclude effects of preferential labeling. An internal standard, created by pooling $15 \mu \mathrm{g}$ of each protein sample, was labeled with $\mathrm{Cy} 2$. Labeling was stopped by adding lysine and equal volume of $2 \times$ IEF buffer ( $8 \mathrm{M}$ Urea, $2 \mathrm{M}$
Thiourea, 4\% CHAPS, 300 mM DTT, 1.0\% IPG buffer 310NL, $0.004 \%$ Broomphenolblue) to each sample.

\section{D-gel electrophoresis and analysis}

Two protein samples (Cy3 and Cy5) were mixed with the Cy2-labeled internal control. Protein samples were passively rehydrated into $24 \mathrm{~cm} \mathrm{pH} \mathrm{3-10} \mathrm{NL} \mathrm{strips} \mathrm{(GE}$ Healthcare, Uppsala, Sweden) for 10 hours followed by isoelectric focusing using a manifold-equipped IPGphor IEF unit (GE Healthcare) according to the manufacturer's protocol. The cysteine sulfhydryls were reduced with $1.0 \%$ DTT and carbamidomethylated with 2.5\% Iodoacetamide in equilibration buffer (30\% glycerol, 2\% SDS, $6 \mathrm{M}$ urea, $75 \mathrm{mM}$ Tris, pH 8.8). Second dimensional SDS-PAGE was performed on hand-cast 12\% SDS-PAGE gels using low fluorescence glass plates. Electrophoresis was carried out at 0.2 watts/gel for 2 hours followed by 1 watts/gel until completion using an Ettan DALT-12 unit (GE Healthcare). Gels were scanned using a Typhoon 9410 imager at $100 \mu \mathrm{m}$ resolution (GE Healthcare). Scan settings were optimized for a maximal signal of 85.000 counts. Gel images were cropped using ImageQuantTL 2003 (GE Healthcare), spot detection was performed with DeCyder 7.0 DIA (Difference In-gel Analysis) software (GE Healthcare) and gel images were matched using DeCyder 7.0 BVA (Biological Variation Analysis) software (GE Healthcare). Statistical analysis was performed using 1-ANOVA DeCyder 7.0 BVA. For 2D-gel analysis $p<0.01$ was considered statistically significant.

\section{Statistical analysis}

Statistical analysis of 2D-DIGE spot intensity was performed using DeCyder 7.0 BVA or EDA software (GE Healthcare, Uppsala, Sweden). Statistical analysis of patient characteristics was performed using an independent sample $t$ tests with statistical software package SPSS 16.0.

\section{Results}

Neutrophils from COPD patients show differentially regulated proteins compared to healthy controls

We first tested the hypothesis whether systemic inflammation in COPD would be reflected by differences in protein expression compared to neutrophil protein expression from healthy control subjects. Therefore, we analyzed the neutrophil proteome from COPD patients and healthy age-matched control subjects by 2D-DIGE. We compared peripheral neutrophil protein expression of 6 healthy age-matched control subjects with those of 13 COPD patients (for demographics see table 1). No significant differences were present in age, weight, length, $\mathrm{BMI}$ or leukocyte count, whereas $\mathrm{FEV}_{1}$, and $\mathrm{FEV}_{1} / \mathrm{FVC}$ ratio were significantly different between the two groups. 
CRP and leukocyte counts were measured as markers for systemic inflammation but no significant differences were found.

Next, we tested whether neutrophils from COPD patients showed significant protein differences compared to healthy controls. Neutrophil protein lysates of freshly isolated neutrophils from healthy controls or COPD patients were prepared, labeled with $\mathrm{Cy} 3$ or $\mathrm{Cy} 5$ and combined with an internal reference control stained with Cy2. Protein samples were separated by 2D-DIGE and analysis with DeCyder 7.0 identified 1200 - 2200 protein spots by a volume filter exclusion of 30.000 in the differential in-gel analysis (DIA) software. The individual spotmaps were matched in the biological variation analysis (BVA) software and statistical analysis between healthy controls and COPD patients showed 7 protein spots that were at least 1.10 -fold differentially regulated with a $p<0.01$ (Figure 1 and Table 2). The peripheral neutrophil spotmaps from COPD patients could be separated in a principal component analysis (PCA) from peripheral neutrophil spotmaps based on the differentially regulated proteins from healthy controls, showing that the differentially regulated proteins have a discriminatory power (Figure 2).

\section{TNF $\alpha$ - and GM-CSF-modulated protein expression of human neutrophils}

The differentially regulated proteins identified in neutrophils from COPD patients might have been induced upon exposure to dominant inflammatory mediators in the peripheral blood. We set out a study in which we compared the profile of neutrophils from COPD patients with in vitro cytokine-stimulated neutrophils to identify proteins that are similarly regulated and predict which

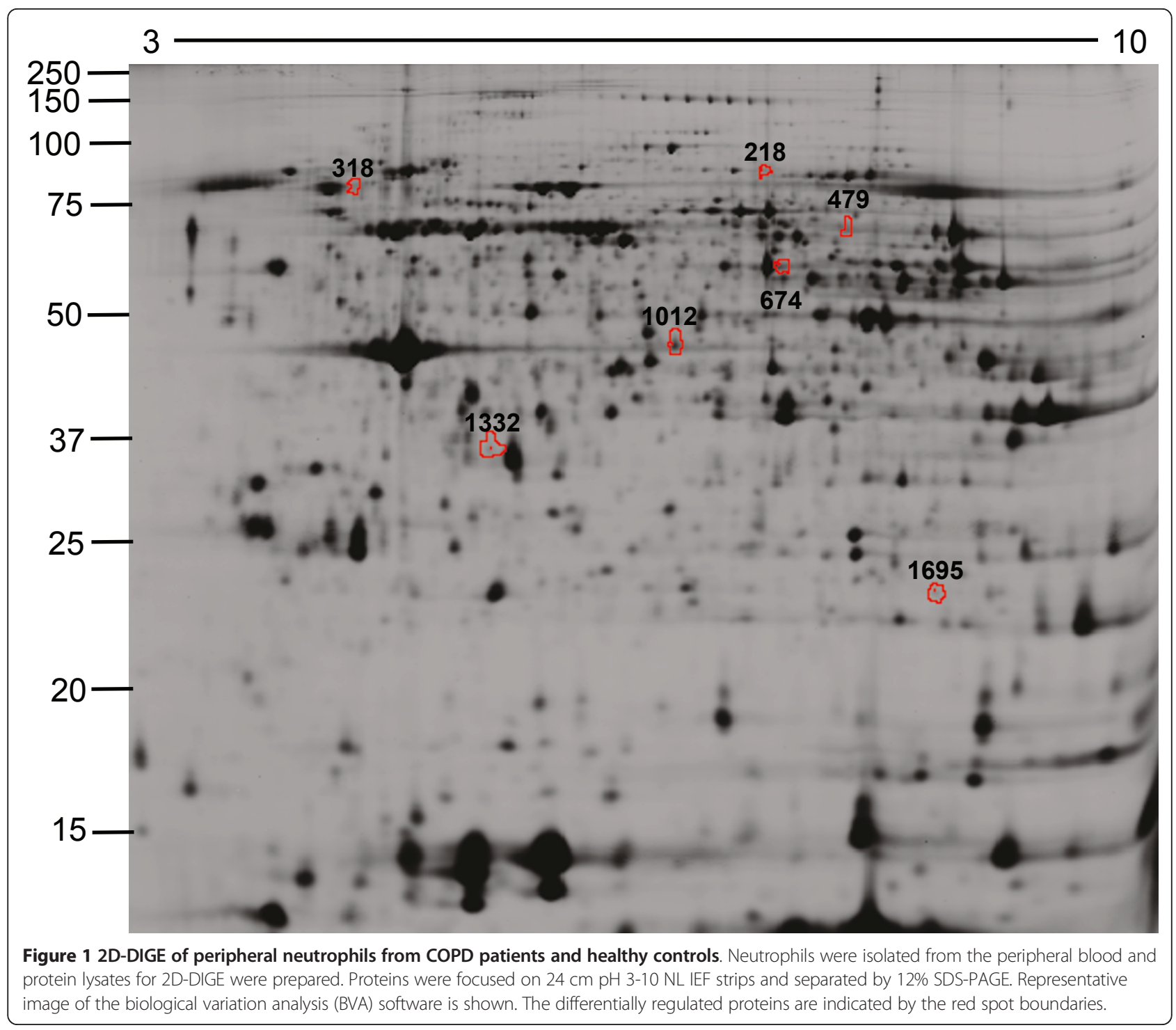




\begin{tabular}{lll}
\hline & No. regulated spots \\
\hline Control vs. COPD & 7 & \\
Not stimulated vs. TNF $\alpha$ & 13 & \\
Not stimulated vs. GM-CSF & 20 & No. regulated spots by GM-CSF \\
Not stimulated vs. TNF $\alpha+$ GM-CSF & 22 & 0 \\
\hline & No. regulated spots in COPD & 20 \\
\hline Control vs. COPD & 7 & 0 \\
Not stimulated vs. GM-CSF & 0
\end{tabular}

cytokine(s) show(s) a predominant role in the systemic inflammation. We tested TNF $\alpha$ and GM-CSF because of their well-documented association with COPD [8,11,12,14-18]. Neutrophils from age-matched healthy controls were either left untreated or stimulated with TNF $\alpha(100 \mathrm{U} / \mathrm{mL})$, GM-CSF (100 pM) or the combination for 4 hours at $37^{\circ} \mathrm{C}$ and, thereafter, protein lysates were made $(n=5)$. Subsequently, samples were labeled with $\mathrm{Cy} 3$ or $\mathrm{Cy} 5$ and were combined with an internal reference control stained with Cy2 and analyzed by 2DDIGE. BVA analysis was performed as described above. Statistical analysis showed 13 protein spots to be differentially regulated more than 1.10-fold (1-ANOVA $p<$ 0.01 ) following TNF $\alpha$ stimulation and 20 protein spots following GM-CSF stimulation, which included the 13

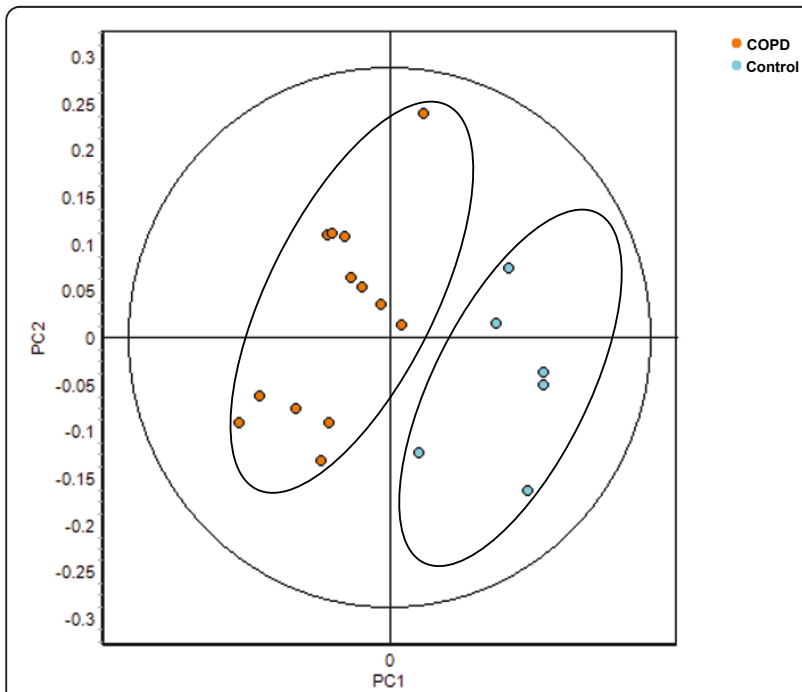

Figure 2 COPD spotmaps were discriminative in a principal component analysis. Data of the significant differential regulated proteins identified in the BVA of peripheral neutrophils from COPD patients (Spot ID 218, 318, 479, 674, 1012, 1332 and 1695) were imported into the extended data analysis (EDA) software. Principal component analysis (PCA) was performed on 6 healthy control (light blue) and 13 COPD (orange) spotmaps.
TNF $\alpha$ regulated protein spots (Table 2). Although TNF $\alpha$ did not show cytokine-specific regulated protein spots, it showed a potentiating effect on multiple GM-CSFinduced protein spots. The combination of TNF $\alpha$ and GM-CSF showed 22 differentially regulated protein spots. Two spots were specifically regulated more than 1.10-fold by the combination of TNF $\alpha+$ GM-CSF.

Differentially regulated proteins in neutrophils from COPD patients do not correspond to differentially regulated protein spots in cytokine-stimulated neutrophils in vitro

GM-CSF and TNF $\alpha$ both induced expression of proteins in neutrophils in vitro and we tested the hypothesis

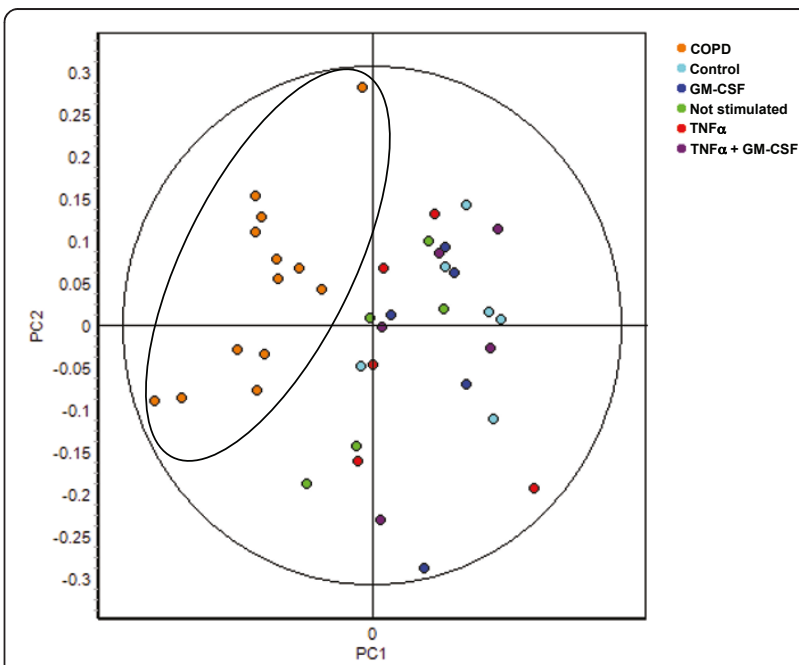

Figure 3 COPD spotmaps did not show a GM-CSF or TNF $\alpha$ induced protein profile in a principal component analysis. Data of spot ID 218, 318, 479, 674, 1012, 1332 and 1695 (differentially regulated in COPD patients) from the COPD patient and in vitro stimulation BVA were imported into the EDA software. Principal component analysis (PCA) was performed on 5 non-stimulated (NS) (green), 5 TNF $\alpha$-stimulated (red), 5 GM-CSF-stimulated (blue), 5

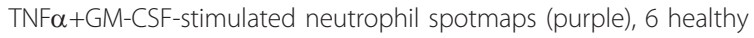
controls (light blue) and 13 COPD neutrophil spotmaps (orange). 
whether these proteins corresponded to differentially regulated proteins in neutrophils from COPD patients. Seven proteins (Figure 1; Spot ID 218, 318, 479, 674, 1012, 1332 and 1695) were significantly different between neutrophils of healthy age-matched controls compared to neutrophils from COPD patients. These seven protein spots were traced back in the 2D-DIGE gels of in vitro stimulated neutrophils. Not any of these 7 protein spots showed differential regulation by GMCSF (Table 2) or TNFa (data not shown). Vice versa, the 20 protein spots that were different between unstimulated neutrophils and GM-CSF stimulated neutrophils in vitro were not differentially regulated between neutrophils of healthy controls and COPD patients (Table 2). As a consequence, the COPD spotmaps (orange) did not cluster with TNF $\alpha$-stimulated neutrophils (red) or GM-CSF-stimulated neutrophils (blue) in the PCA, based on the differentially regulated proteins in COPD patients (Figure 3). Therefore, this analysis shows that the protein profiles of COPD patients are not reflected by GM-CSF and/or TNF $\alpha$-stimulated peripheral neutrophil profiles.

\section{Discussion}

Increased neutrophil numbers and multiple inflammatory mediators have been found in sputum, bronchoalveolar lavage (BAL) fluid, bronchial biopsies and peripheral blood of COPD patients [8-12,25-27]. Therefore, we set out experiments to measure the neutrophil protein expression ex vivo as a means to identify cytokines that are dominant in the systemic inflammation in COPD patients. We have used 2D-DIGE, a novel technique that uses an internal reference sample in all 2D-gels, which enables the identification of protein expression differences as small as $10 \%$ [24]. Although the control group only includes 6 subjects, in-vitro stimulation of these neutrophils showed reproducible differences in protein expression. Furthermore, various 2D-DIGE publications have used similar group sizes [28-30]. Therefore, this technique is suitable to detect protein expression differences in relatively small study groups.

We performed for the first time 2D-DIGE on peripheral neutrophils from stable COPD patients and age-matched healthy control subjects and identified 7 significant (1ANOVA $p<0.01$ ) protein differences. A limitation of the study is the lack of an age-matched control group that smokes but do not have signs of COPD. The possible confounder in our study is that the differences found between healthy controls and COPD patients are smoking related and not disease related. Therefore, in additional PCA comparisons we excluded spotmaps from current smokers from the COPD group, which did not affect the clustering (data not shown). Also, comparing spotmaps from COPD patients with control spotmaps of either ex-smokers or non-smokers in the PCA showed clustering of COPD spotmaps apart from control spotmaps (data not shown). Based on these observations we find it unlikely that smoking is the reason for the differential neutrophil protein expression found in the COPD patients. Therefore, we hypothesize that the protein differences represent a baseline systemic inflammation in COPD patients. The protein differences found in neutrophils from COPD patients were subsequently compared with in vitro cytokine-stimulated neutrophils. For this approach, we selected in vitro stimulation with TNF $\alpha$ and/or GM-CSF because these cytokines are extensively described to be involved in the inflammation and pathogenesis of COPD. TNFa is an interesting cytokine in regard to systemic inflammation because it is linked to extrapulmonary manifestations of COPD such as osteopenia [31] and muscle wasting [32]. An important pathway induced by TNF $\alpha$ is the NF- $\kappa \mathrm{B}$ pathway, and increased NF- $\kappa$ B activity has been shown in sputum neutrophils [33] and macrophages [34] of COPD patients. Also, GM-CSF is an important cytokine in the pathogenesis of COPD. Recently, Vlahos et. al. showed that mice exposed to cigarette smoke that were treated with neutralizing antibodies against GM-CSF exhibited reduced BAL fluid macrophages and neutrophils [13]. Also, TNFa, MIP-2 and MMP-12 mRNA levels were reduced in the lungs of anti-GM-CSF treated mice. This shows that GM-CSF is a key mediator in smoke-induced airway inflammation. We have previously shown that in vitro stimulation of neutrophils with either TNF $\alpha$ or GMCSF resulted in differential expression of genes encoding for chemokines and cytokines [21]. In our current proteomics approach in vitro stimulation of peripheral neutrophils with TNF $\alpha$ or GM-CSF resulted in differential protein expression of 13 and 20 protein spots, respectively. All proteins regulated by TNFa were also regulated by GM-CSF, showing that both cytokines show redundancy in regulating protein expression. It is surprising that TNF $\alpha$ did not show cytokine-specific regulation of protein spots because it is an important stimulator for the NF- $\kappa$ B pathway, regulating multiple inflammatory mediators that are not regulated by GM-CSF [21]. Indeed, we previously showed that TNF- $\alpha$ increased the expression of chemokines in neutrophils on mRNA level in vitro [21]. Also, we have confirmed TNF- $\alpha$-induced production of IL- $1 \beta$ on protein level in neutrophils in vitro [35]. A possible explanation could be that the expression levels of these inflammatory mediators in the neutrophils are too low to be detected by 2D-DIGE.

GM-CSF-induced protein expression in neutrophils in vitro was compared with protein expression of neutrophils from COPD patients. Protein differences that were found in neutrophils from COPD patients did not correspond to protein differences found in GM-CSF-stimulated neutrophils (Figure 3, Table 2). It is very well possible that other 
inflammatory mediators next to GM-CSF modulated protein expression in peripheral neutrophils from COPD patients. For instance, increased levels of IL-6, IL-8, and CRP were found in the peripheral blood op COPD patients [36,37]. Which of these factors, or combination of factors, play a role in the regulation of neutrophil proteins in COPD patients is currently not known. At least, we can exclude a prominent role for TNF $\alpha$ or GM-CSF on peripheral blood neutrophils. The identification of the differentially regulated neutrophil protein spots from COPD patients by mass spectrometry might delineate the inflammatory factors involved in neutrophil protein regulation in vivo, however, this was not the aim of this investigation.

Our data do not support the hypothesis that TNF $\alpha$ and GM-CSF drive systemic inflammation in stable COPD patients with a normal BMI (Table 1). Interestingly, we did not find increased hsCRP levels in our cohort of COPD patients, which is a marker for systemic inflammation. The most likely explanation for the low C-reactive protein (CRP) levels is the strict inclusion of stable COPD patients. Indeed, increased levels of acute phase proteins such as fibrinogen or CRP in COPD patients are mainly found during exacerbations [37-42]. Apparently, the differences found in the neutrophil proteome are not caused by an acute phase systemic inflammation since CRP levels were not significantly different between our included COPD patients and age-matched healthy control subjects.

\section{Conclusion}

Systemic inflammation in COPD was determined by the analysis of the proteomes of peripheral blood neutrophils. The proteomes of the peripheral neutrophils of the COPD patients were not similar to peripheral neutrophils stimulated by TNFa and/or GM-CSF, neither did they correlate with increases in CRP. This indicates that systemic inflammation in COPD as visualized by peripheral neutrophil protein profiles is caused by a unique but subtle interplay between multiple inflammatory signals.

\section{Acknowledgements}

This work was supported by the Dutch Asthma Foundation Grant 3.2.03.63.

\section{Authors' contributions}

JDL performed in vitro proteome preparation of neutrophils, analysis of neutrophil profiles using DeCyder software, statistical analysis and prepared the manuscript. RCS recruited and documented the subjects and assisted with the design of the study and manuscript preparation. JWJL assisted with the design of the study and manuscript preparation. LK conceived and designed the study, and assisted with manuscript preparation. LU designed the study and prepared manuscript and assisted with in vitro neutrophil preparations. All authors read and approved the manuscript.

\section{Competing interests}

The authors declare that they have no competing interests.
References

1. Global Initiative for Chronic Obstructive Lung Disease. Global Strategy for the Diagnosis, Management and Prevention of Chronic Obstructive Pulmonary Disease. [http://www.goldcopd.com/], Date last updated: December 2009.

2. Agusti AG, Noguera A, Sauleda J, Sala E, Pons J, Busquets X: Systemic effects of chronic obstructive pulmonary disease. Eur Respir J 2003, 21(2):347-360.

3. Oudijk EJ, Lammers JW, Koenderman L: Systemic inflammation in chronic obstructive pulmonary disease. Eur Respir J Supp/ 2003, 46:5s-13s.

4. Barnes PJ, Celli BR: Systemic manifestations and comorbidities of COPD. Eur Respir J 2009, 33(5):1165-1185.

5. Chung KF: Cytokines in chronic obstructive pulmonary disease. Eur Respir J Supp/ 2001, 34:50s-59s

6. Dubar V, Gosset P, Aerts C, Voisin C, Wallaert B, Tonnel AB: In vitro acute effects of tobacco smoke on tumor necrosis factor alpha and interleukin-6 production by alveolar macrophages. Exp Lung Res 1993, 19(3):345-359.

7. Culpitt SV, Rogers DF, Shah P, De Matos C, Russell RE, Donnelly LE, Barnes PJ: Impaired inhibition by dexamethasone of cytokine release by alveolar macrophages from patients with chronic obstructive pulmonary disease. Am J Respir Crit Care Med 2003, 167(1):24-31.

8. Balbi B, Bason C, Balleari E, Fiasella F, Pesci A, Ghio R, Fabiano F: Increased bronchoalveolar granulocytes and granulocyte/macrophage colonystimulating factor during exacerbations of chronic bronchitis. Eur Respir J 1997, 10(4):846-850.

9. Cheng SL, Wang HC, Yu CJ, Yang PC: Increased expression of placenta growth factor in COPD. Thorax 2008, 63(6):500-506.

10. Tumkaya M, Atis S, Ozge C, Delialioglu N, Polat G, Kanik A: Relationship between airway colonization, inflammation and exacerbation frequency in COPD. Respir Med 2007, 101(4):729-737.

11. Dentener MA, Louis $R$, Cloots $R H$, Henket M, Wouters EF: Differences in local versus systemic TNFalpha production in COPD: inhibitory effect of hyaluronan on LPS induced blood cell TNFalpha release. Thorax 2006, 61(6):478-484

12. Saha S, Doe C, Mistry V, Siddiqui S, Parker D, Sleeman M, Cohen ES, Brightling CE: Granulocyte-macrophage colony-stimulating factor expression in induced sputum and bronchial mucosa in asthma and COPD. Thorax 2009, 64(8):671-676.

13. Vlahos R, Bozinovski S, Chan SP, Ivanov S, Linden A, Hamilton JA, Anderson GP: Neutralizing granulocyte/macrophage colony-stimulating factor inhibits cigarette smoke-induced lung inflammation. Am J Respir Crit Care Med 182(1):34-40.

14. Gessner C, Scheibe R, Wotzel M, Hammerschmidt S, Kuhn H, Engelmann L, Hoheisel G, Gillissen A, Sack U, Wirtz H: Exhaled breath condensate cytokine patterns in chronic obstructive pulmonary disease. Respir Med 2005, 99(10):1229-1240.

15. Keatings VM, Collins PD, Scott DM, Barnes PJ: Differences in interleukin-8 and tumor necrosis factor-alpha in induced sputum from patients with chronic obstructive pulmonary disease or asthma. Am J Respir Crit Care Med 1996, 153(2):530-534.

16. Di Francia M, Barbier D, Mege $J$, Orehek J: Tumor necrosis factor-alpha levels and weight loss in chronic obstructive pulmonary disease. Am J Respir Crit Care Med 1994, 150(5 Pt 1):1453-1455.

17. Takabatake N, Nakamura H, Abe S, Inoue S, Hino T, Saito H, Yuki H, Kato S, Tomoike $\mathrm{H}$ : The relationship between chronic hypoxemia and activation of the tumor necrosis factor-alpha system in patients with chronic obstructive pulmonary disease. Am J Respir Crit Care Med 2000, 161(4 Pt 1):1179-1184.

18. Vernooy JH, Kucukaycan M, Jacobs JA, Chavannes NH, Buurman WA, Dentener MA, Wouters EF: Local and systemic inflammation in patients with chronic obstructive pulmonary disease: soluble tumor necrosis factor receptors are increased in sputum. Am J Respir Crit Care Med 2002, 166(9):1218-1224.

19. Sapey E, Ahmad A, Bayley D, Newbold P, Snell N, Rugman P, Stockley RA: Imbalances between interleukin-1 and tumor necrosis factor agonists and antagonists in stable COPD. J Clin Immunol 2009, 29(4):508-516.

20. Langereis JD, Oudijk EJ, Schweizer RC, Lammers JW, Koenderman L, Ulfman LH: Steroids induce a disequilibrium of secreted interleukin-1 receptor antagonist and interleukin-1\{beta\} synthesis by human neutrophils. Eur Respir J 2011, 37(2):406-415. 
21. Oudijk EJ, Nijhuis EH, Zwank MD, van de Graaf EA, Mager HJ, Coffer PJ, Lammers JW, Koenderman L: Systemic inflammation in COPD visualised by gene profiling in peripheral blood neutrophils. Thorax 2005, 60(7):538-544.

22. Oudijk EJ, Lo Tam Loi AT, Langereis JD, Ulfman LH, Koenderman L: Functional antagonism by GM-CSF on TNF-alpha-induced CD83 expression in human neutrophils. Mol Immunol 2008, 46(1):91-96.

23. Mahler DA, Wells CK: Evaluation of clinical methods for rating dyspnea. Chest 1988, 93(3):580-586.

24. Tonge R, Shaw J, Middleton B, Rowlinson R, Rayner S, Young J, Pognan F, Hawkins E, Currie I, Davison M: Validation and development of fluorescence two-dimensional differential gel electrophoresis proteomics technology. Proteomics 2001, 1(3):377-396.

25. Peleman RA, Rytila PH, Kips JC, Joos GF, Pauwels RA: The cellular composition of induced sputum in chronic obstructive pulmonary disease. Eur Respir J 1999, 13(4):839-843.

26. Di Stefano A, Capelli A, Lusuardi M, Balbo P, Vecchio C, Maestrelli P, Mapp CE, Fabbri LM, Donner CF, Saetta M: Severity of airflow limitation is associated with severity of airway inflammation in smokers. Am J Respir Crit Care Med 1998, 158(4):1277-1285.

27. Sparrow D, Glynn RJ, Cohen M, Weiss ST: The relationship of the peripheral leukocyte count and cigarette smoking to pulmonary function among adult men. Chest 1984, 86(3):383-386.

28. Fessler MB, Malcolm KC, Duncan MW, Worthen GS: A genomic and proteomic analysis of activation of the human neutrophil by lipopolysaccharide and its mediation by p38 mitogen-activated protein kinase. J Biol Chem 2002, 277(35):31291-31302.

29. Langereis JD, Prinsen BH, de Sain-van der Velden MG, Coppens CJ, Koenderman L, Ulfman LH: A 2D-DIGE approach to identify proteins involved in inside-out control of integrins. J Proteome Res 2009, 8(8):3824-3833.

30. Shimada S, Nakamura M, Tanaka Y, Tsutsumi K, Katano M, Masuko K, Yudoh K, Koizuka I, Kato T: Crosslinking of the CD69 molecule enhances S100A9 production in activated neutrophils. Microbiol Immunol 2007, 51(1):87-98.

31. Bolton CE, lonescu AA, Shiels KM, Pettit RJ, Edwards PH, Stone MD, Nixon LS, Evans WD, Griffiths TL, Shale DJ: Associated loss of fat-free mass and bone mineral density in chronic obstructive pulmonary disease. Am J Respir Crit Care Med 2004, 170(12):1286-1293.

32. Wouters EF, Creutzberg EC, Schols AM: Systemic effects in COPD. Chest 2002, 121(5 Suppl):127S-130S.

33. Brown V, Elborn JS, Bradley J, Ennis M: Dysregulated apoptosis and NFkappaB expression in COPD subjects. Respir Res 2009, 10:24.

34. Caramori G, Romagnoli M, Casolari P, Bellettato C, Casoni G, Boschetto P, Chung KF, Barnes PJ, Adcock IM, Ciaccia A, et al: Nuclear localisation of p65 in sputum macrophages but not in sputum neutrophils during COPD exacerbations. Thorax 2003, 58(4):348-351.

35. Langereis JD, Oudijk EJ, Schweizer RC, Lammers JW, Koenderman L, Ulfman LH: Steroids induce a disequilibrium of sIL-1Ra and IL-1\{beta\} synthesis by human neutrophils. Eur Respir $J$.

36. Piehl-Aulin K, Jones I, Lindvall B, Magnuson A, Abdel-Halim SM: Increased serum inflammatory markers in the absence of clinical and skeletal muscle inflammation in patients with chronic obstructive pulmonary disease. Respiration 2009, 78(2):191-196.

37. de Torres JP, Cordoba-Lanus E, Lopez-Aguilar C, Muros de Fuentes M, Montejo de Garcini A, Aguirre-Jaime A, Celli BR, Casanova C: C-reactive protein levels and clinically important predictive outcomes in stable COPD patients. Eur Respir J 2006, 27(5):902-907.

38. Alessandri C, Basili S, Violi F, Ferroni P, Gazzaniga PP, Cordova C: Hypercoagulability state in patients with chronic obstructive pulmonary disease. Chronic Obstructive Bronchitis and Haemostasis Group. Thrombosis and haemostasis 1994, 72(3):343-346.

39. Dahl M, Tybjaerg-Hansen A, Vestbo J, Lange P, Nordestgaard BG: Elevated plasma fibrinogen associated with reduced pulmonary function and increased risk of chronic obstructive pulmonary disease. Am J Respir Crit Care Med 2001, 164(6):1008-1011.

40. Dev D, Wallace E, Sankaran R, Cunniffe J, Govan JR, Wathen CG, Emmanuel FX: Value of C-reactive protein measurements in exacerbations of chronic obstructive pulmonary disease. Respir Med 1998, 92(4):664-667.
41. Perera WR, Hurst JR, Wilkinson TM, Sapsford RJ, Mullerova H, Donaldson GC, Wedzicha JA: Inflammatory changes, recovery and recurrence at COPD exacerbation. Eur Respir J 2007, 29(3):527-534.

42. Dentener MA, Creutzberg EC, Schols AM, Mantovani A, van't Veer C, Buurman WA, Wouters EF: Systemic anti-inflammatory mediators in COPD: increase in soluble interleukin 1 receptor II during treatment of exacerbations. Thorax 2001, 56(9):721-726.

\section{Pre-publication history}

The pre-publication history for this paper can be accessed here: http://www.biomedcentral.com/1471-2466/11/44/prepub

doi:10.1186/1471-2466-11-44

Cite this article as: Langereis et al:: A unique protein profile of peripheral neutrophils from COPD patients does not reflect cytokineinduced protein profiles of neutrophils in vitro. BMC Pulmonary Medicine 2011 11:44.

\section{Submit your next manuscript to BioMed Central and take full advantage of:}

- Convenient online submission

- Thorough peer review

- No space constraints or color figure charges

- Immediate publication on acceptance

- Inclusion in PubMed, CAS, Scopus and Google Scholar

- Research which is freely available for redistribution 